\title{
RANTAI PASOK PRODUK BERAS DI KECAMATAN CIBEBER, KABUPATEN CIANJUR
}

\author{
THE RICE SUPPLY CHAIN IN CIBEBER DISTRICT OF CIANJUR REGENCY
}

\author{
Alexandro Ephannuel Saragih*1, Netti Tinaprilla*), dan Amzul Rifin*) \\ ${ }^{*}$ Departemen Agribisnis, Fakultas Ekonomi dan Manajemen, Institut Pertanian Bogor \\ Jl. Kamper, Wing 4 Level 5 Kampus IPB Dramaga, Bogor 16680
}

\begin{abstract}
Integration in supply chain is the key of marketing. The objectives of this research were to identify the rice supply chain in Cibeber District in Cianjur Regency, to analyze the technical efficiency and vertical integration in the rice supply chain. Although the amount of rice product sold in Cipinang market is only small, the Cipinang grading system remains as a reference for the members of the rice supply chain in Cianjur. There were 10 marketing channels of rice product in Cibeber. Overall, the technical efficiency value of all channels had good scores, and this could be influenced by the sharing information process. Only four out of ten channels that had the technical efficiency, and this was caused by the large number of institutions involved in these channels. There was a directional causality from the farmers of Cibeber, Cianjur to the collectors and retailers of Cianjur. This represents that farmers' power was not weak in the rice supply chain. The government needs to consistently oversee the rice storage performed by the wholesalers, especially in Cipinang Market. The increasing rice price in the wholesalers or retails was not caused by the increasing rice price the farmer level, but it was caused by the wholesaler market power to influence the rice supply in the market
\end{abstract}

Keywords: rice, supply chain, technical efficiency, vertical integration

\begin{abstract}
Abstrak: Integrasi rantai pasok merupakan kunci pemasaran. Penelitian ini bertujuan mengidentifikasi rantai pasok beras di Kecamatan Cibeber, Kabupaten Cianjur. Penelitian juga bertujuan menganalisis efisiensi teknis dan integrasi pasar vertikal pada rantai pasok beras tersebut. Meskipun aliran produk beras dari Cianjur ke Pasar Cipinang hanya dengan jumlah kecil, sistem grading di Pasar Induk Cipinang sering menjadi acuan bagi anggota rantai pasok produk beras di Cianjur. Terdapat 10 saluran pemasaran produk beras dari Cibeber, Cianjur. Secara umum, nilai efisiensi teknis seluruh saluran telah cukup baik. Hal ini dapat disebabkan adanya pembagian informasi yang baik diantara anggota rantai pasok. Berdasarkan efisiensi teknis, terdapat empat saluran rantai pasok yang tidak efisien dari total 10 saluran. Saluran menjadi tidak efisien karena banyaknya jumlah lembaga pelaku rantai pasok yang terlibat. Harga gabah di tingkat petani di Cibeber, Cianjur dapat memengaruhi harga beras di tingkat pedagang pengumpul besar dan pengecer, namun tidak berlaku sebaliknya. Hal ini menunjukkan bahwa posisi petani pada rantai pasok beras tidak lemah. Pemerintah perlu terus mengawasi proses penyimpanan beras oleh pedagang besar, terutama di Pasar Cipinang. Kenaikan harga beras di pasar bukan karena kenaikan harga gabah di petani, namun dapat disebabkan kemampuan pedagang besar untuk memengaruhi pasokan beras di tingkat pasar.
\end{abstract}

Kata kunci: efisiensi teknis, integrasi vertikal, rantai pasok, beras

\footnotetext{
${ }^{1}$ Corresponding author:

Email: alexandroesaragih@gmail.com
} 


\section{PENDAHULUAN}

Indonesia merupakan salah satu negara dengan tingkat konsumsi beras tertinggi di dunia. Rata-rata konsumsi beras per kapita mencapai 98,05 kg/tahun (SUSENAS, 2015 dalam PUSDATIN, 2016). Beras memang telah menjadi makanan pokok bagi masyarakat Indonesia. Hal ini mengimplikasikan dibutuhkannya usaha peningkatan produksi beras dalam negeri. Namun, program peningkatan produksi beras tidak akan dapat berjalan dengan efektif apabila sistem pemasaran tidak efisien (Sultana, 2012). Rantai pasok merupakan kegiatan yang melibatkan semua pihak, baik yang memproduksi atau menghasilkan jasa, mulai dari produsen sampai ke konsumen akhir. Adanya integrasi dan koordinasi yang baik antara anggota rantai pasok menjadi kunci dalam proses pemasaran suatu produk. Selain aliran produk, aliran finansial dan informasi dalam rantai pasok sangat menentukan kesuksesan atau kinerja rantai pasok (Lakollo, 2012).

Proses gabah dari petani menjadi beras melibatkan sejumlah lembaga untuk sampai menjadi beras yang siap dikonsumsi. Jumlah lembaga yang terlibat dapat memengaruhi besarnya biaya dalam saluran rantai pasok. Efisiensi dari setiap biaya pemasaran terhadap keuntungan yang dihasilkan menjadi sangat penting diperhatikan agar rantai pasok suatu produk beras dapat bersaing dengan rantai pasok beras lainnya.
Di sisi lain, penggunaan biaya pada rantai pasok telah efisien. Namun, harga beras pada setiap level pasar yang terlibat, belum tentu terintegrasi dengan baik. Hal tersebut dapat disebabkan penyalahgunaan market power pedagang perantara dalam rantai pasok (Meyer dan Taubadel, 2004). Disparitas harga beras di Indonesia pada tingkat pengecer dengan harga gabah kering panen (GKP) pada tingkat petani, cenderung meningkat dari tahun 2011-2014 (BPS, 2016). Hal tersebut ditunjukkan oleh Gambar 1. Disparitas tersebut dipengaruhi oleh biaya pemasaran, banyaknya lembaga yang terlibat, dan market power pedagang perantara yang terlibat. Disparitas harga yang cenderung meningkat menunjukkan bahwa marjin pemasaran semakin besar. Marjin yang semakin besar tersebut dapat mengindikasikan pula lemahnya integrasi pasar dan rendahnya efisiensi pemasaran pada lembagalembaga pemasaran beras yang terlibat di Indonesia (Aryani, 2012).

Kecamatan Cibeber, Cianjur merupakan salah satu daerah unggulan tanaman pangan komoditas padi di Kabupaten Cianjur menurut Surat Keputusan Bupati Nomor 520/KEP.240-DISTAN/2012. Gabah, sebagai hasil panen petani di daerah ini, tentunya membutuhkan penanganan aliran produk yang efisien. Saluran-saluran pemasaran beras yang berasal dari daerah ini perlu dievaluasi dan dibandingkan untuk melihat potensi peningkatan efisiensi pemasaran beras dari daerah ini.

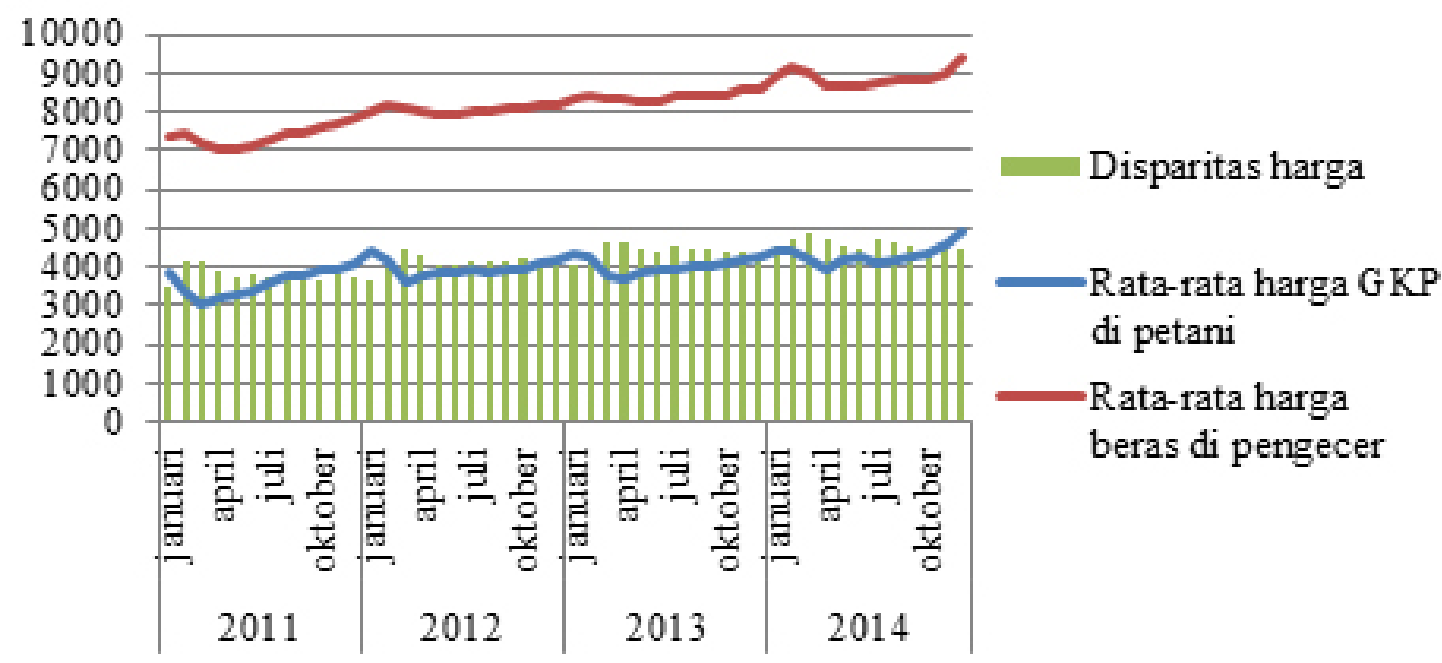

Gambar 1. Pergerakan rata-rata harga beras pengecer dan gabah kering panen (GKP) Petani di Indonesia pada Januari 2011-Desember 2014 (BPS, 2015) 
Secara umum, petani di Kecamatan Cibeber, Cianjur memiliki skala usaha yang kecil. Petani cenderung ingin praktis menjual hasil panennya dalam bentuk gabah kering panen (GKP). Petani di Cibeber masih sangat tergantung kepada pemilik modal yang dapat mengolah hasil panen atau gabahnya (Aji et al. 2014). Pemilik modal yang dimaksud adalah pabrik beras yang membeli gabah dari petani, melalui tengkulak, dengan menggunakan pembayaran uang tunai secara cepat. Kondisi tersebut dapat memengaruhi lemahnya integrasi harganya dengan anggota rantai pasok lainnya (Mafimisebi et al. 2014; Mkpado et al. 2013; Purwono et al. 2013).

Selain petani di Cibeber, terdapat lembaga lain yang terlibat dalam rantai pasok seperti penggilingan padi dan pedagang beras. Anggota rantai pasok dengan skala usaha yang besar, memiliki potensi sebagai koordinator atau acuan bagi anggota rantai pasok lainnya. Kekuatan yang berbeda diantara anggota rantai pasok yang terlibat dalam mengalirkan beras, dapat memengaruhi arah transmisi harga pada rantai pasok tersebut (Revoredo et al. dalam Hermawan et al. 2008). Beras dari Cibeber, Cianjur banyak dipasarkan ke Pasar Induk Cipinang melalui pedagang yang memiliki kapasitas penyimpanan yang besar dan cenderung mengarah ke struktur oligopoli. Hal ini dapat menjadi sumber lemahnya integrasi pasar dan transmisi harga yang bersifat asimetri.

Integrasi pasar pada pemasaran beras di Cibeber, Cianjur juga dipasarkan ke Pasar Induk Cipinang, penting untuk dievaluasi. Pasar yang terintegrasi merupakan indikator bahwa sistem pemasaran telah efisien. Menurut Aryani (2012), dalam jangka pendek, harga gabah petani dipengaruhi oleh harga beras pengecer di Indonesia. Namun, harga gabah petani tidak memengaruhi harga beras di tingkat pengecer. Hal tersebut berbeda dengan kondisi pasar beras di Nigeria, dimana arah transmisi harga adalah dari petani ke distributor dan pengecer (Jezghani et al. 2011). Analisis integrasi dan transmisi harga di tingkat lembaga pemasaran beras menjadi penting dievaluasi untuk menggambarkan kekuatan lembaga tersebut pada rantai pasok. Hasil analisis tersebut sangat dibutuhkan sebagai dasar dalam mengambil tindakan yang dapat mendukung kelancaran rantai pasok beras.

Berdasarkan latar belakang dan perumusan masalah yang telah diuraikan, tujuan penelitian ini adalah mengidentifikasi rantai pasok beras di Kecamatan
Cibeber, Kabupaten Cianjur, mengevaluasi efisiensi teknis setiap saluran dalam rantai pasok beras, dan mengevaluasi integrasi pasar vertikal pada rantai pasok beras.

\section{METODE PENELITIAN}

Lokasi yang dipilih dalam penelitian ini adalah Kecamatan Cibeber, Kabupaten Cianjur. Penelitian dilakukan di 3 desa sampel yang mewakili 18 desa di Kecamatan tersebut. Ketiga desa yang dipilih yakni Desa Salamnunggal, Karangnunggal dan Cisalak. Pengumpulan data dilakukan pada Bulan Juli 2015.

Data primer bersumber dari hasil wawancara dan observasi. Petani yang terlibat sebagai responden awal adalah 30 orang. Pengambilan sampel ini dilakukan dengan metode multistage sampling dari 3 desa. Peneliti mengambil 10 orang petani responden dari masing-masing desa. Dari informasi petani, diketahui aliran produk yang melibatkan lembaga pemasaran lainnya. Lembaga tersebut adalah, 4 orang pedagang pengumpul (tengkulak), 1 penggilingan desa, 2 pedagang pengumpul besar, 1 pabrik beras, 3 pedagang besar di Cianjur, 3 pedagang beras di Pasar Cipinang, dan 6 pengecer.

Data sekunder berasal dari buku, jurnal, dan penelitian sebelumnya, seperti hasil penelitian Saragih (2014), terkait nilai efisiensi operasional pada saluran pemasaran beras di Cianjur. Selain itu, data bulanan dari Dinas Pertanian Kabupaten Cianjur, terkait harga gabah di tingkat petani, harga beras di pedagang pengumpul besar dan pengecer, sejak Januari 2012 sampai Desember 2014. Data sekunder lainnya, yakni data bulanan terkait harga beras di Pasar Cipinang (Jakarta) pada Januari 2012 sampai Desember 2014 yang digunakan dalam mengevaluasi integrasi harga vertikal pada rantai pasok beras dari Kabupaten Cianjur untuk tujuan Pasar Cipinang.

Analisis kualitatif digunakan menganalisis rantai pasok dengan menggunakan kerangka Food Supply Chain Network (FSCN). Analisis kuantitatif digunakan untuk menganalisis integrasi pasar vertikal pada rantai pasok beras, melalui metode Vector Autoregression (VAR). Kerangka pemikiran penelitian ditunjukkan oleh Gambar 2. Dalam pengolahan data, peneliti menggunakan software Eviews 8. Efisiensi rantai pasok juga dilihat berdasarkan efisiensi teknis setiap saluran 
rantai pasok yang ada dengan metode DEA. Dalam pengolahan data, peneliti menggunakan software Max DEA Pro 6.4.

\section{Analisis rantai pasok beras}

Menurut Van der Vorst (2006), untuk membahas potensi atau pengembangan rantai pasok, dibutuhkan kerangka untuk mendeskripsikan rantai pasok tersebut. Kerangka analisis deskriptif rantai pasok ditunjukkan oleh Gambar 3.

\section{Efisiensi teknis saluran rantai pasok}

Metode Data Envelopment Analysis (DEA) merupakan suatu metode untuk mengevaluasi efisiensi dari suatu unit pengambilan keputusan atau DMU (decisionmaking unit). Analisis DEA berdasarkan evaluasi terhadap efisiensi relatif dari DMU yang sebanding.
DMU yang efisien akan membentuk garis frontier. Apabila DMU berada pada garis frontier maka DMU tersebut relatif efisien dibandingkan DMU lain dalam groupnya. Melalui DEA, ditunjukkan pula DMU yang dapat menjadi referensi bagi DMU yang tidak efisien (Chen dan Lin, 2014).

Efisiensi teknis saluran rantai pasok dapat diukur dengan menjadikan saluran sebagai DMU. Hal tersebut,DMU diukur efisiensinya melalui metode DEA. Dalam penelitian ini, DMU yang digunakan adalah 10 saluran rantai pasok beras di Kecamatan Cibeber, Kabupaten Cianjur berdasarkan penelitian Saragih (2014). Input yang dipilih dalam mengevaluasi efisiensi teknis saluran rantai pasok adalah marjin pemasaran dan biaya pemasaran. Sebaliknya, output yang dipilih adalah nilai farmer's share, rasio keuntungan terhadap biaya, dan keuntungan pada setiap saluran rantai pasok.

- Pemasaran beras yang efisien dibutuhkan karena beras menjadi kebutuhan pokok masyarakat Indonesia

- Rantai pasok yang terintegrasi menjadi kunci pemasaran yang efisien

- Disparitas harga beras di tingkat petani dengan pengecer pada tahun 2011-2014 mengindikasikan integrasi pasar yang cenderung melemah

- Pentingnya mengetahui arah dan kecepatan transmisi harga pada setiap level pasar untuk mengambarkan kekuatannya pada rantai pasok

- Kecamatan Cibeber sebagai daerah unggulan produsen gabah di Kabupaten Cianjur

- Aliran produk beras dari Cibeber melibatkan pedagang dengan modal dan kapasitas penyimpanan yang kuat

- Rata-rata petani memiliki skala usaha yang kecil dan menjual hasil panennya dalam bentuk GKP

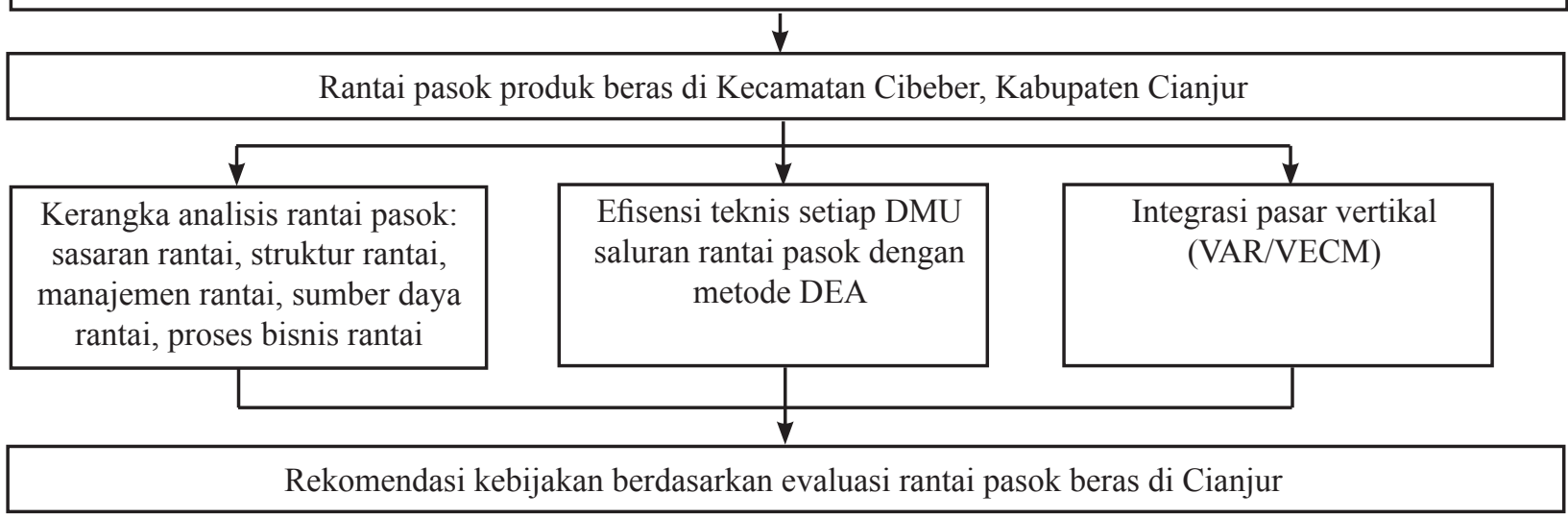

Gambar 2. Kerangka pemikiran penelitian 


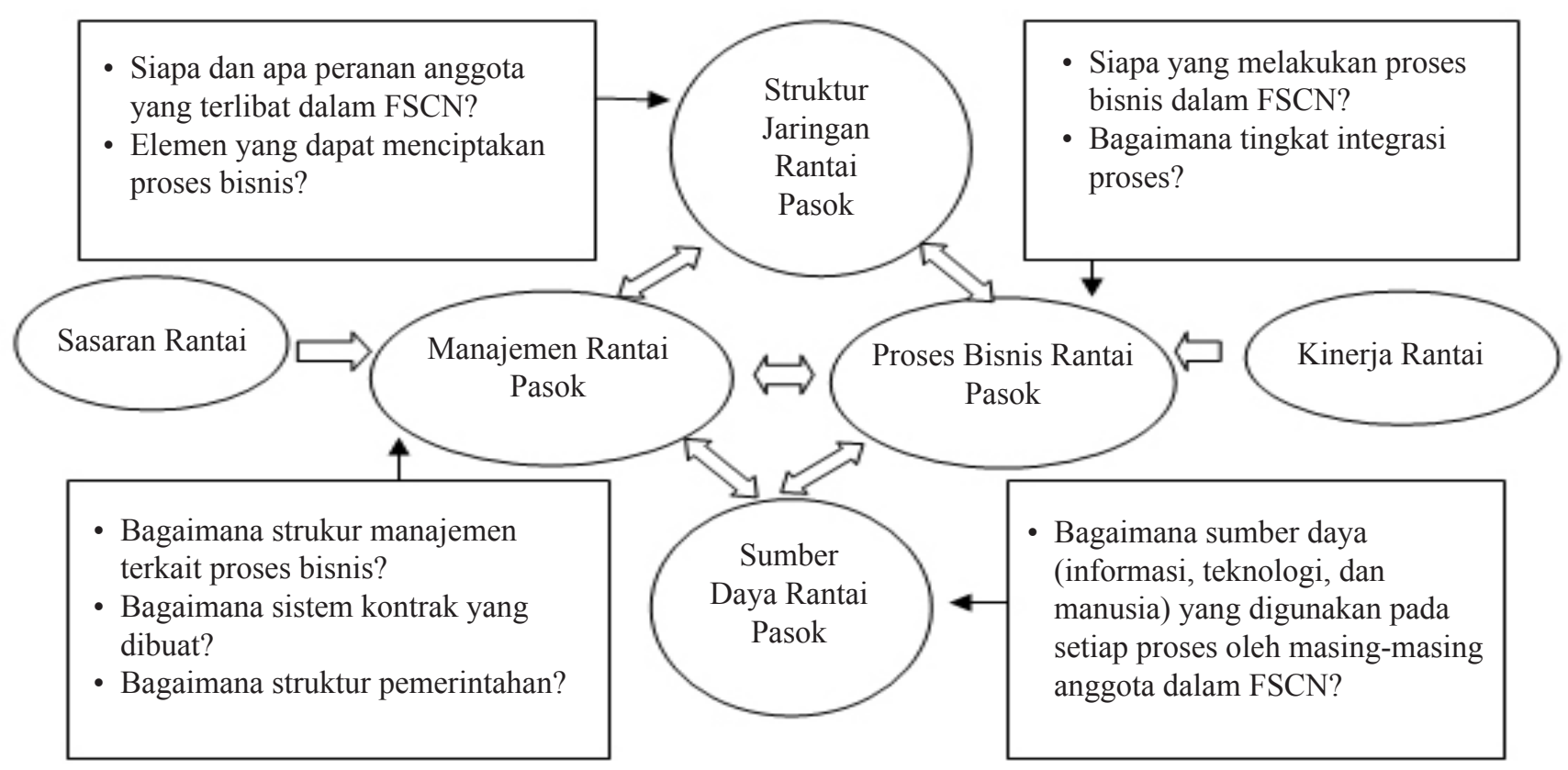

Gambar 3. Kerangka analisis deskriptif rantai pasok (Van der Vorst, 2006)

\section{Integrasi pasar}

Integrasi pasar yang dianalisis pada penelitian ini adalah integrasi harga vertikal. Integrasi pasar vertikal menunjukkan pengaruh harga di suatu lembaga terhadap pembentukan harga suatu komoditas di tingkat lembaga lainnya. Lembaga yang dimaksud dalam penelitian ini adalah petani di Cibeber Kabupaten Cianjur, pedagang pengumpul besar di Cianjur, pedagang pengecer di Cianjur, dan pedagang di Pasar Cipinang (Jakarta). Analisis integrasi harga vertikal dalam penelitian ini diukur dengan metode VAR. Metode tersebut dilakukan dengan tahapan-tahapan pada Gambar 4. Sebelum dilakukan estimasi model VAR, uji kausalitas juga dilakukan dengan metode granger. Uji kausalitas adalah pengujian untuk menentukan hubungan sebab-akibat antar peubah dalam sistem VAR. Uji ini menunjukkan apakah suatu variabel mempunyai hubungan dua arah atau hanya satu arah saja. Model VAR dapat pula digunakan melihat dampak perubahan dari suatu peubah terhadap peubah lain dalam sistem secara dinamis. Hal ini dilakukan dengan memberikan guncangan (shocks) pada salah satu peubah endogen. Dalam penelitian ini, peubah yang dimaksud adalah harga gabah di tingkat petani Cibeber Kabupaten Cianjur, harga beras di pedagang pengumpul besar, pedagang pengecer Cianjur, dan harga beras di pedagang Pasar Cipinang. Pengaruh guncangan sebesar satu standar deviasi yang dialami oleh satu peubah dalam sistem terhadap nilai-nilai peubah saat ini dan beberapa periode mendatang disebut sebagai teknik Impulse Response Function (IRF).

\section{HASIL}

\section{Kondisi Rantai Pasok Beras di Kecamatan Cibeber, Cianjur}

Konsumen beras dari Cianjur ini bukan hanya berasal dari daerah tersebut, tetapi juga banyak di kota lain seperti Jakarta, Bogor, Depok. Produk beras yang berasal dari rantai pasok di Cianjur memiliki merek yang berbeda-beda. Pabrik beras pada umumnya mencantumkan merek pabrik tersebut. Citra rasa beras Cianjur yang baik sering menjadikan banyak pihak menggunakan istilah beras Cianjur pada produknya. Penjualan beras mulai dari pabrik, penggilingan padi, pedagang besar, sampai ke pengecer menerapkan sistem grading.

Terdapat beberapa lembaga yang menjadi anggota rantai pasok beras di Kecamatan Cibeber, yakni:

\section{Petani}

Hampir seluruh petani menjual hasil panennya dalam bentuk gabah kering panen (GKP). Hal ini disebabkan kebutuhan petani akan uang tunai secara langsung, petani yang tidak memiliki lantai jemur, dan petani tidak mau menambah beban kerjanya (Sobichin, 2012). Terdapat tiga pilihan tujuan penjualan gabah bagi petani, yakni pedagang pengumpul (tengkulak), penggilingan padi desa, dan pedagang pengumpul besar. Adanya alternatif pilihan tujuan penjualan bagi petani mengimplikasikan bahwa petani sebenarnya tidak 
selalu berada pada posisi yang lemah. Saat mendekati masa panen, banyak tengkulak yang datang ke petani secara langsung untuk berusaha membeli hasil panen petani. Saat petani merasa dirugikan, petani memiliki kebebasan untuk beralih kepada tujuan penjualan lain, yakni ke penggilingan desa dan pengumpul besar. Namun, apabila petani ingin menjual gabah ke lembaga-lembaga tersebut, petani harus mengantarkan sendiri hasil panennya ke lokasi penggilingan desa atau pedagang pengumpul besar tersebut.

\section{Pedagang Pengumpul (Tengkulak)}

Dibandingkan dengan petani, pedagang pengumpul (tengkulak) memperoleh rata-rata harga pembelian gabah yang lebih tinggi oleh pengumpul besar sebesar Rp100. Petani tidak memperoleh harga yang lebih baik apabila secara langsung menjual gabahnya kepada pengumpul besar. Sebagian besar tengkulak membeli hasil panen petani dalam bentuk GKP dan menjualnya kembali ke lembaga lainnya dalam bentuk GKP juga. Tengkulak, saat melakukan pembelian, juga memeriksa kualitas gabah terutama kadar airnya, butir hampa, dan butir kuning atau butir rusak. Tidak terdapat alat ukur dalam penentuan kualitas gabah, namun hanya menggunakan penglihatan saja. Selisih gabah yang baik dan buruk dapat mencapai Rp300. Namun, biasanya posisi tengkulak lebih kuat dalam menentukan kualitas gabah dibandingkan posisi petani (Maulana \& Rachman dalam Maulana, 2012).

\section{Penggilingan (desa)}

Penggilingan tingkat desa biasanya berkapasitas lebih kecil dibandingkan pabrik beras, yakni menghasilkan $65 \mathrm{~kg}$ beras setiap hari. Harga pembelian gabah oleh penggilingan ini biasanya lebih rendah dari harga pembelian yang dilakukan oleh pengumpul besar. Penggilingan sering menjadi pilihan karena lokasinya yang sangat berdekatan dengan lahan petani. Beras yang dijual kepada pengecer atau konsumen yang datang secara langsung, dijual menggunakan karung polos.

\section{Pengumpul Besar}

Anggota rantai pasok di Kabupaten Cianjur yang bukan hanya berfungsi sebagai pengolah gabah menjadi beras, namun juga membeli gabah dari tengkulak atau petani secara langsung untuk dijual ke pabrik beras yang lebih besar skala usahanya. Di sisi lain, sebagian gabah yang dijemur menjadi GKG kemudian diolah, disortir kembali, dan dikemas. Beras kemudian dijual ke pedagang besar di Kabupaten Cianjur atau pengecer di luar Kabupaten.

\section{Pabrik Beras}

Pabrik beras yang dimaksud pada bagian ini adalah pabrik beras yang memperoleh gabah dari pengumpul besar. Sistem grading juga dilakukan oleh pabrik beras, baik saat menerima gabah maupun menjual beras. Saat melakukan pengolahan gabah, pabrik juga menghasilkan dedak, abu padi, dan sekam yang dapat dijual atau digunakan kembali. Pabrik beras merupakan anggota rantai pasok yang paling mengalami kesulitan saat tidak mendapatkan pasokan gabah. Pabrik akan dirugikan karena pabrik telah mengeluarkan biaya tetap dalam jumlah besar, seperti biaya mesin dan alat terkait kegiatan pengolahan. Untuk memenuhi kepastian pasokan gabahnya, pabrik bahkan memiliki jaringan pengumpul dari luar daerahnya.

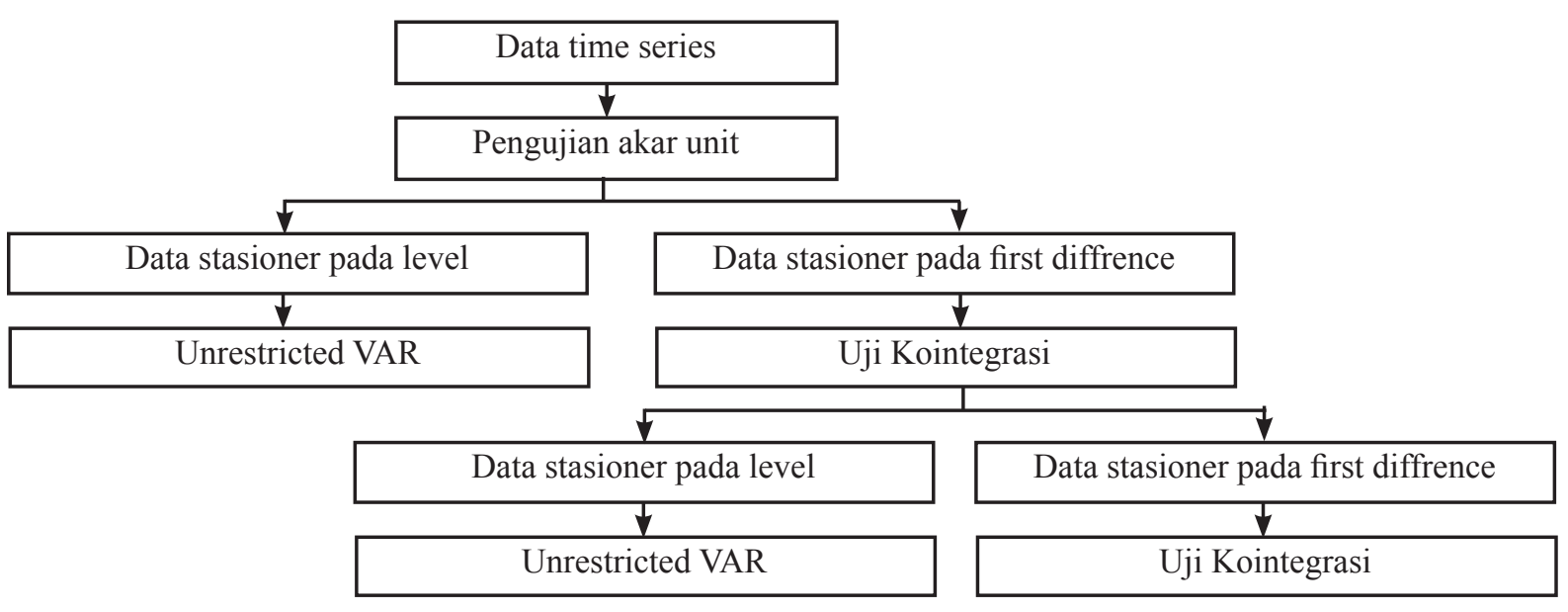

Gambar 4. Sistematika Pengolahan Vector Autoregression (VAR) (Juanda dan Junaidi, 2012) 
Saat panen raya, pabrik beras relatif lebih mudah untuk mendapatkan pasokan gabah dari pengumpul besar di Cianjur. Namun, saat musim paceklik, pabrik biasanya harus mencari gabah dari pengumpul besar diluar Cianjur, seperti dari pedagang pengumpul besar di Karawang.

\section{Pedagang Besar di Tingkat Kabupaten}

Pedagang besar tidak memiliki fungsi pengolahan. Sistem grading juga dilakukan oleh pedagang besar. Beberapa hal yang harus diperhatikan dalam sistem grading adalah derajat sosoh beras, warna dan aroma beras, butir patah, dan banyaknya kotoran yang tercampur dalam beras. Rata-rata pedagang besar di Cianjur tersebut memiliki gudang penyimpanan dengan kapasitas 10 ton beras. Saat musim paceklik, pedagang besar juga berusaha mendapatkan pasokan beras dari pabrik beras di luar Cianjur, seperti dari pabrik beras di Karawang.

\section{Pedagang Pasar Induk Cipinang (luar kabupaten)}

Pasar Cipinang berjarak sekitar $118 \mathrm{~km}$ dari Kecamatan Cibeber. Rasio produk beras dari Cianjur yang masuk ke Pasar Cipinang sebenarnya relatif sedikit, yakni sekitar 1,14\% dari total beras yang masuk (Food Station Tjipinang Jaya 2009 dalam Surjasa et al. 2013). Pemasok utama ke Pasar Cipinang berasal dari Karawang dan Cirebon. Namun, beras dari Cianjur dikategorikan sebagai beras premium, dimana harganya dapat lebih tinggi sekitar Rp2.000/kg dibandingkan dengan harga beras dari daerah lain.

Pedagang di Pasar Cipinang memiliki gudang penyimpanan yang cukup besar untuk menyimpan beras. Setiap gudang penyimpanan yang dimiliki oleh pedagang di Cipinang bahkan dapat menampung lebih dari 500 ton beras. Standar penetapan grade beras oleh pedagang di Pasar Cipinang ini sering menjadi acuan bagi pabrik beras dan anggota rantai pasok sebelumnya.

\section{Pedagang Pengecer}

Pedagang pengecer pada umumnya tidak melakukan fungsi pengangkutan. Beras yang diantar oleh pemasok kepadanya, akan dijual kembali pada konsumen yang datang kepadanya. Pada umumnya, harga pada setiap kualitas beras yang ditetapkan oleh pemasok menjadi acuan juga pada pengecer.
Terdapat 10 saluran rantai pasok beras dari Cibeber, Cianjur. Aliran beras juga melibatkan pedagang di luar Cianjur (Bank Indonesia, 2015; Mardianto et al. 2005). Pedagang pengumpul (tengkulak) merupakan lembaga yang paling dominan dipilih petani (Ariwibowo, 2013; Sobichin, 2012), yakni 96,47\%. Tidak terdapat kelompok tani atau Bulog yang menjadi anggota rantai pasok beras dari Cibeber, Cianjur. Aktivitas kelompok tani masih terbatas pada kegiatan budidaya dan penyaluran bantuan dari pemerintah seperti yang terjadi di Kabupaten Batang (Sobichin, 2012). Sepuluh saluran tersebut adalah sebagai berikut:

1. Petani-Pedagang Pengumpul (Tengkulak)Penggilingan (desa)-Pengecer (kabupaten)Konsumen

2. Petani-Penggilingan Padi (desa)-Pedagang Pengecer (kabupaten)-Konsumen

3. Petani-Pedagang Pengumpul (Tengkulak)Penggilingan Padi (desa)-Konsumen

4. Petani- Pedagang Pengumpul (Tengkulak)Pengumpul Besar-Pedagang Besar (kabupaten)Pedagang Pengecer (kabupaten)-Konsumen

5. Petani- Pedagang Pengumpul (Tengkulak)Pengumpul Besar-Pedagang Besar (kabupaten)Konsumen

6. Petani-Pengumpul Besar-Pedagang Besar (kabupaten)-Pedagang Pengecer (kabupaten)Konsumen

7. Petani-Pengumpul Besar-Pedagang Besar (kabupaten)-Konsumen

8. Petani- Pedagang Pengumpul (Tengkulak)Pengumpul Besar-Pedagang Pengecer (luar kabupaten)-Konsumen

9. Petani- Pedagang Pengumpul (Tengkulak)Pengumpul Besar-Pabrik Beras-Pasar Induk Cipinang (luar kabupaten)-Pedagang Pengecer (luar kabupaten)-Konsumen

10.Petani-Pengumpul Besar-Pabrik Beras-Pedagang Pasar Induk Cipinang (luar kabupetan) -Pedagang Pengecer (luar kabupaten)-Konsumen

Secara umum, proses transaksi atau aliran finansial antara pihak-pihak yang bermitra relatif cepat. Hal ini mempertimbangkan kebutuhan modal oleh semua anggota rantai pasok untuk melanjutkan atau mengembangkan usahanya. Selain itu, hal tersebut memang dibutuhkan untuk menciptakan kepuasan bagi pihak-pihak yang bermitra. 
Aliran informasi pada rantai pasok beras di Cibeber Cianjur berlangsung secara timbal-balik mulai dari petani sampai pada ke konsumen akhir. Hal ini berbeda dengan aliran produk dan finansial yang bersifat satu arah. Pembagian informasi diantara anggota rantai pasok seperti masalah budi daya, jumlah produksi dan kualitas gabah petani, informasi harga beras di pasar.

Proses kemitraan hanya terjadi diantara pedagang pengumpul (tengkulak) dengan pengumpul besar. Tengkulak yang mendapatkan gabah dari petani hanya akan melakukan penjualan kepada pengumpul besar yang menjadi mitranya. Tengkulak yang menjadi mitra pengumpul besar biasanya juga memperoleh bantuan pinjaman modal tanpa bunga dari pengumpul besar saat akan melakukan pembelian kepada petani. Semua kesepakatan antar anggota rantai pasok bersifat informal. Kepercayaan diantara anggota rantai pasok juga semakin kuat apabila anggota rantai pasok yang bermitra dapat selalu memenuhi kesepakatan yang telah dibuat. Proses-proses tersebut juga dapat diperlancar dengan adanya komunikasi yang baik dan terbuka antara pihak-pihak yang bermitra.

Di sisi lain, pemerintah juga berusaha mendukung kelancaran rantai pasok produk beras di Cianjur. Pemerintah memberikan bantuan sarana produksi, uang tunai sebagai modal, informasi teknologi seperti jarak tanam jajar legowo dan penggunaan bibit unggul kepada petani melalui kelompok tani. Kebijakan Harga Pembelian Pemerintah (HPP) terhadap gabah petani juga ditetapkan untuk melindungi petani, yakni
Rp3.700/kg gabah (BPS, 2016). Informasi standar mutu beras juga dikeluarkan pemerintah sebagai acuan bagi anggota rantai pasok.

\section{Efisiensi Teknis Setiap Saluran Rantai Pasok}

Berdasarkan hasil pengolahan menggunakan DEA, nilai seluruh decision making unit tinggi, yakni diatas 0,90. Terdapat 4 rantai pasok produk beras di Kecamatan Cibeber Kabupaten Cianjur yang masih belum efisien dari total 10 saluran yang ada. Hal ini ditunjukkan melalui nilai efisensi teknis saluran 1, 4, 6, dan 9 yang memiliki nilai efisiensi kurang dari 1 . Nilai efisensi teknis decision making unit rantai pasok ditunjukkan pada Gambar 5.

Meskipun keempat saluran tersebut belum efisien, namun nilai efisiensi teknisnya sebenarnya masih cukup baik dibandingkan saluran lainnya. Hal ini ditunjukkan oleh nilai efisensi terkecil pada saluran 4 sebesar 0,988 . Artinya, secara operasional atau teknis, saluran pemasaran beras dari Kecamatan Cibeber, Cianjur masih cukup baik. Hal ini dapat disebabkan adanya integrasi yang telah cukup baik pada rantai pasok tersebut. Pembagian informasi yang baik diantara anggota rantai pasok menjadi salah satu indikator baiknya proses integrasi. Informasi seperti harga dan kualitas beras, kendala produksi di tingkat petani, dibagikan dengan baik oleh anggota rantai pasok. Berikut merupakan Tabel 1 yang menunjukkan besarnya rata-rata target yang harus dicapai agar saluran yang tidak efisien menjadi efisien.

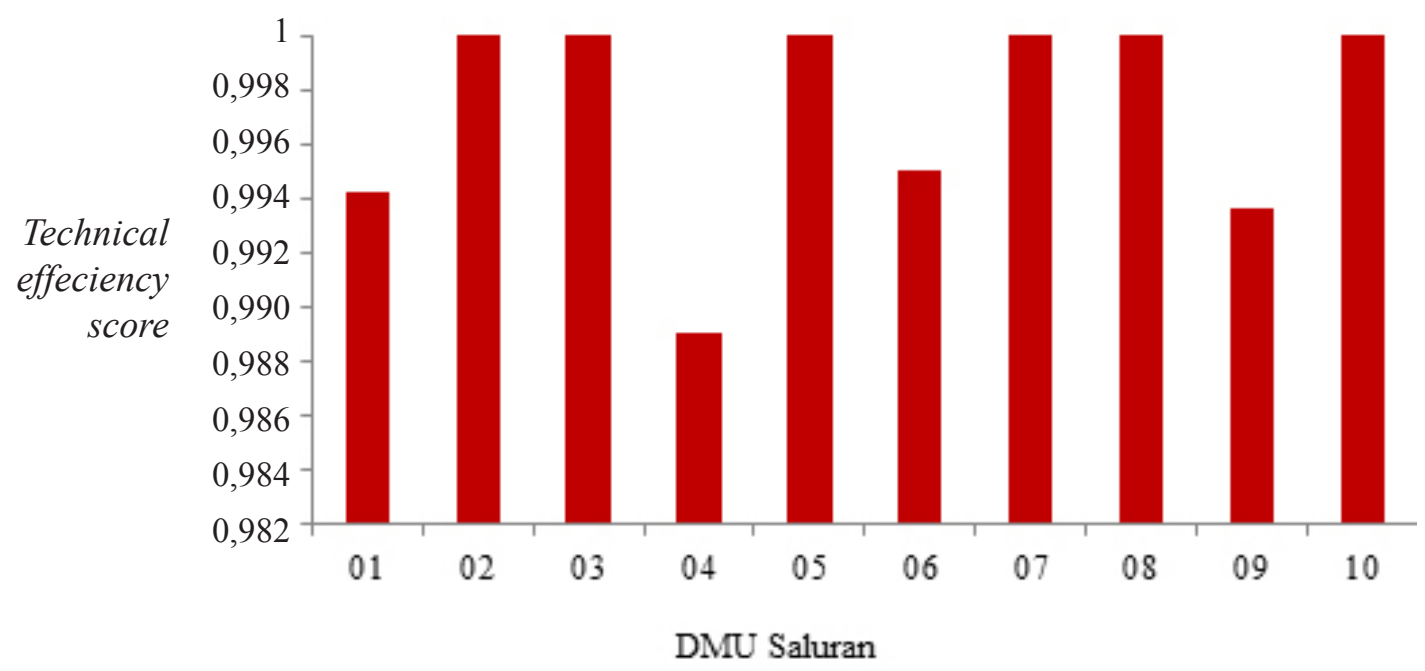

Gambar 5. Sebaran skor efisiensi teknis rantai pasok beras di Kabupaten Cianjur dengan Model DEA VRS pada setiap rantai pasok 
Tabel 1. Rata-rata potential improvement saluran $(1,4,6,9)$

\begin{tabular}{llrrr}
\hline Faktor & Variabel & Aktual & Target & Potential Improvements \\
\hline Input & Biaya pemasaran & $2.402,27$ & $2.344,44$ & $-57,83(2,41 \%)$ \\
& Marjin pemasaran & 5.150 & $5.111,31$ & $-38,69(0,75 \%)$ \\
Output & Farmer's share & 41,59 & 42,05 & $0,46(1,10 \%)$ \\
& Keuntungan & $2.747,73$ & $2.766,86$ & $19,14(0,70 \%)$ \\
& Rasio keuntungan terhadap biaya & 1,08 & 1,10 & $0,02(2,04 \%)$ \\
\hline
\end{tabular}

Pedagang pengumpul (tengkulak) merupakan lembaga yang terlibat pada 3 dari 4 saluran yang tidak efisien. Tengkulak terdapat pada saluran 1, 4, dan 9. Tengkulak, sebagai lembaga yang hanya berfungsi sebagai penjual dan pembeli GKP, dapat menjadi penyebab saluran menjadi tidak efisien. Pada umumnya, tengkulak hanya menjadi kaki tangan dari pengumpul besar atau penggilingan padi. Modal yang digunakan tengkulak merupakan pinjaman dari pengumpul besar atau penggilingan padi. Tengkulak memang merupakan mitra bagi pengumpul besar karena dapat menjamin adanya pasokan gabah bagi pengumpul. Namun, pada pada jangka panjang, keberadaan tengkulak tersebut tentu akan dapat terancam karena menyebabkan saluran menjadi tidak efisien. Apabila pengumpul telah memiliki jaringan petani pemasok gabah yang baik, tengkulak tentu dapat tereliminasi dari saluran tersebut. Selain tengkulak, terdapat lembaga lain yang terlibat pada 3 dari 4 saluran yang tidak efisien. Lembaga tersebut adalah pengumpul besar. Lembaga tersebut terlibat pada saluran 4, 6, dan 9. Namun, lembaga tersebut tentu tidak dapat tereliminasi dari saluran karena lembaga tersebut memiliki fungsi yang sangat penting, yakni mengolah gabah menjadi beras. Selain itu, pedagang pengumpul besar juga punya akses pasar baik ke hulu maupun ke hilir.

\section{Integrasi Pasar}

Arah transmisi harga pada rantai pasok beras di Kecamatan Cibeber, Cianjur adalah dari petani ke pedagang pengumpul besar dan pedagang pengecer di Cianjur (Jezghani et al. 2011). Petani memiliki pengaruh karena pasokan gabah petani memang sangat dibutuhkan oleh pengolah atau pabrik penggilingan padi. Tanpa gabah dari petani, pabrik dapat mengalami kerugian karena pabrik telah mengeluarkan biaya yang besar untuk pengadaan mesin pengolahan. Namun, perubahan harga gabah di tingkat petani Kecamatan Cibeber, Cianjur tidak menyebabkan perubahan harga beras di Pasar Cipinang. Hal ini dapat disebabkan rasio beras yang masuk ke Pasar Cipinang memang hanya sedikit, yakni kurang dari 5\%. Artinya, peningkatan harga pembelian gabah, hanya akan meningkatkan harga beras di Cianjur itu sendiri. Namun, hal tersebut tidak akan menaikkan harga beras di perkotaan seperti Jakarta (Hermawan et al. 2008). Di sisi lain, perubahan harga beras di Pasar Cipinang dapat memengaruhi harga beras di tingkat pedagang pengumpul besar dan pengecer Cianjur.

Harga beras di pedagang pengumpul besar Cianjur, pengecer Cianjur, dan pedagang Pasar Cipinang, menjadi variabel bebas dalam persamaan integrasi harga vertikal. Pada jangka panjang, semua variabel tersebut terkointegrasi terhadap harga gabah di tingkat petani Cianjur. Hal ini mengimpikasikan bahwa beras memang masih menjadi makanan pokok bagi penduduk Indonesia, sehingga pergerakan harga pada anggota rantai pasok lain tergantung pada harga gabah di tingkat petani, dalam jangka panjang (Ohen dan Abang, 2011). Namun, hanya harga beras di pedagang pengumpul besar Cianjur saja yang memiliki hubungan positif dengan harga gabah di petani Cianjur. Sebaliknya, harga beras di pedagang pengecer Cianjur dan pedagang Pasar Cipinang justru memiliki hubungan negatif dalam jangka panjang. Tidak turunnya harga beras di tingkat pedagang saat harga gabah petani telah turun, dapat disebabkan oleh adanya aktivitas penyimpanan. Beras merupakan komoditas yang dapat disimpan dalam waktu yang cukup lama. Pedagang tidak akan merespon harga input atau gabah dengan mengubah harga output atau beras, namun dengan mengubah jumlah pasokan di pasar (Revoredo et al. dalam Hermawan et al. 2008).

Koefisien error correction term (ECT) pedagang pengumpul besar adalah -0,171048, signifikan pada taraf nyata $5 \%$, menunjukkan bahwa fluktuasi keseimbangan jangka pendek akan dikoreksi menuju kesimbangan jangka panjang. Sekitar $17,10 \%$ proses penyesuaiannya terjadi pada bulan pertama. 
Dalam jangka pendek, harga gabah di petani Cianjur hanya dipengaruhi oleh harga gabah itu sendiri pada satu bulan sebelumnya. Apabila terjadi penurunan harga gabah pada satu bulan sebelumnya sebesar 1 satuan maka akan meningkatkan harga gabah sebesar 0,571852 pada bulan berikutnya. Di sisi lain, dalam jangka pendek, harga gabah di petani Cibeber, Cianjur juga berhubungan negatif dengan harga beras di pedagang pengecer Cianjur. Apabila harga gabah di petani di Cibeber, Cianjur pada satu bulan sebelumnya turun sebesar 1 satuan maka akan menyebabkan kenaikan harga beras di tingkat pedagang pengecer Cianjur sebesar 0,517258. Pedagang pengecer atau pedagang akan menganggap penurunan harga gabah di petani hanya akan bersifat sementara. Penurunan tersebut akan diikuti oleh intervensi pemerintah untuk melindungi petani sehingga harga gabah akan kembali naik (Firdaussy, 2012). Di sisi lain, harga beras di tingkat pedagang pengumpul besar dan pedagang Pasar Cipinang ternyata hanya dipengaruhi oleh hubungan keseimbangan jangka panjangnya.

Saluran 4 merupakan saluran yang memiliki nilai efisiensi teknis terkecil dibandingkan saluran lainnya. Saluran ini juga melibatkan pedagang pengumpul besar dan pengecer di Cianjur. Berdasarkan analisis IRF, terdapat perbedaan respons apabila terjadi guncangan pada masing-masing lembaga tersebut. Sejak bulan pertama, pengecer Cianjur mengalami dampak yang cukup besar apabila terjadi guncangan harga di pedagang pengumpul besar. Waktu penyesuaian sehingga dampak tersebut menjadi stabil, baru terjadi sejak bulan kelima. Di sisi lain, dampak yang dirasakan oleh pengumpul relatif lebih kecil apabila terjadi guncangan harga di tingkat pedagang pengecer Cianjur. Guncangan harga beras di pedagang pengecer Cianjur tersebut bahkan tidak berdampak bagi pedagang pengumpul besar pada bulan pertama. Kondisi ini dapat mengimplikasikan pula bahwa memang terdapat lembaga-lembaga rantai pasok dengan kekuatan yang berbeda pada saluran 4 tersebut.

Berdasarkan analisis IRF, guncangan harga beras di pedagang pengecer Cianjur dan pedagang di luar Cianjur, yakni pedagang di Pasar Cipinang, samasama tidak memiliki dampak yang besar bagi harga gabah di tingkat petani di Cibeber, Cianjur. Artinya, petani di Cianjur sebenarnya tidak merasakan dampak yang khusus apabila beras dari hasil olahan gabahnya, berikutnya dijual di dalam atau di luar Cianjur. Di sisi lain, pedagang di Pasar Cipinang juga tidak merasakan dampak yang besar apabila terjadi guncangan harga beras pada anggota rantai pasok lainnya.

\section{Implikasi Manajerial}

Petani membutuhkan kecepatan dalam proses pembayaran terhadap hasil panennya. Hal ini sangat perlu diperhatikan oleh lembaga pengolah atau pabrik beras yang ingin mendapatkan gabah dari petani. Pabrik harus terus melakukan pengolahan karena lembaga tersebut telah mengeluarkan biaya yang besar dalam pengadaan sumber daya. Jadi, pabrik juga memiliki ketergantungan yang cukup tinggi terhadap gabah dari petani. Implikasinya, pabrik harus dapat memenuhi kebutuhan petani tersebut. Pabrik beras harus mendorong para pedagang pengumpul (tengkulak) untuk melakukan pembayaran secara cepat kepada petani. Kondisi tersebut berbeda dengan pedagang. Dibandingkan dengan pabrik, pedagang pengecer beras akan lebih mudah mengalihkan jenis usahanya. Pedagang pengecer dapat memanfaatkan lokasi penjualannya untuk menjual hal lain, selain beras. Sedangkan untuk para pedagang di Pasar Cipinang, tidak terdapat ketergantungan yang tinggi terhadap gabah dari petani di Cianjur. Para pedagang di Pasar Cipinang, dengan kapasitas gudang penyimpanan yang besar, telah memiliki jaringan pemasok beras dari sejumlah daerah lain di Indonesia.

\section{KESIMPULAN DAN SARAN}

\section{Kesimpulan}

Produk beras dari Cibeber, Cianjur, bukan hanya dialirkan di Pasar Cianjur, tetapi juga ke kota lain seperti ke Pasar Cipinang. Aliran beras tersebut melibatkan pedagang di Pasar Cipinang. Meskipun demikian, aliran beras dari Cianjur ke Pasar Cipinang hanya sedikit. Namun, sistem grading di pasar tersebut sering menjadi acuan bagi anggota rantai pasok beras di Cianjur. Berdasarkan integrasi pasar vertikal, pedagang di Pasar Cipinang bahkan dapat memengaruhi harga beras di tingkat pengumpul besar dan pengecer Cianjur. Pabrik beras merupakan anggota rantai pasok yang paling mengalami kesulitan saat tidak mendapatkan pasokan gabah dari petani. Pada saat panen raya, petani dilindungi oleh pemerintah melalui kebijakan harga pembelian pemerintah (HPP). Di sisi lain, Aliran 
finansial diantara anggota rantai pasok cukup cepat. Hal ini menjadi penting bagi anggota rantai pasok untuk dapat bersaing dalam memperoleh pasokan gabah atau beras.

Berdasarkan efisiensi teknis saluran rantai pasok, masih hanya 6 dari 10 saluran yang nilai efisiensinya bernilai 1. Namun, secara umum nilai efisiensi masing-masing saluran telah cukup baik. Hal ini disebabkan integrasi rantai pasok telah berlangsung cukup baik. Saluran 4 (petani-tengkulak-pengumpul besar-pedagang besarpengecer-konsumen) merupakan saluran yang paling tidak efisien. Saluran menjadi tidak efisien karena banyaknya jumlah lembaga terlibat. Selain itu, saluran menjadi tidak efisien karena harga penjualan ke konsumen akhirCianjur yang lebih rendah dibandingkan harga konsumen di Jakarta.

Hasil analisis integrasi harga, harga gabah di tingkat petani Cianjur dapat memengaruhi harga beras di tingkat pengumpul besar dan pengecer, namun tidak berlaku sebaliknya. Hal ini mengimplikasikan bahwa posisi petani tidak lemah pada rantai pasok beras. Petani memiliki pilihan tujuan dalam menjual gabahnya, yakni tengkulak, penggilingan, dan pengumpul besar. Berdasarkan analisis IRF, harga gabah di tingkat petani Cianjur juga mengalami dampak yang sangat kecil apabila terjadi guncangan harga beras pada anggota rantai pasok lainnya. Namun, petani tidak dapat memengaruhi harga beras di pedagang Pasar Cipinang. Posisi pedagang tersebut kuat karena memiliki persediaan beras dalam jumlah besar. Selain itu, pedagang tersebut memiliki jaringan pemasok beras dari berbagai daerah. Berdasarkan analisis IRF, harga beras di tingkat pedagang tersebut juga mengalami dampak yang sangat kecil apabila terjadi guncangan pada anggota rantai pasok beras lainnya.

\section{Saran}

Aktivitas distribusi beras oleh anggota rantai pasok ke luar Cianjur, seperti Pasar Cipinang, dapat meningkatkan harga jual berasnya. Namun, aktivitas penjualan ini juga perlu memperhatikan jumlah lembaga yang terlibat agar tetap efisien. Pabrik beras dan pedagang pengumpul besar harus dapat menjamin pembayaran secara cepat terhadap hasil panen yang dibeli dari petani agar dapat bersaing dalam rantai pasok. Selanjutnya, pemerintah perlu terus mengawasi proses penyimpanan beras oleh pedagang besar, terutama di Cipinang. Penyebab kenaikan harga beras di pasar bukan karena kenaikan harga gabah di petani. Namun, dapat disebabkan kemampuan pedagang untuk memengaruhi pasokan beras di tingkat pasar.

\section{DAFTAR PUSTAKA}

Aji AA, Satria A, Hariono B. 2014. Strategi pengembangan agribisnis komoditas padi dalam meningkatkan ketahanan pangan Kabupaten Jember. Jurnal Manajemen dan Agribisnis 11(1): $60-67$.

Ariwibowo A. 2013. Analisis rantai distribusi komoditas padi dan beras di Kecamatan Pati Kabupaten Pati. Economics Development Analysis Journal 2(2): 1-9.

Aryani D. 2012. Integrasi vertikal pasar produsen gabah dengan pasar ritel beras di Indonesia. Jurnal Manajemen Teknologi 11(2):225-238.

Bank Indonesia. 2015. Skema pembiayaan pertanian dengan pendekatan konsep rantai nilai. http:// www.bi.go.id/id/umkm/penelitian/nasional/ kajian. [20 Desember 2015].

[BPS]. Badan Pusat Statistik. 2015. Harga gabah dan beras. http://www.bps.go.id. [20 Desember 2015].

[BPS]. Badan Pusat Statistik. 2016. HPP gabah. http:// www.bps.go.id. [17 Maret 2017].

Chen Y, Lin X. 2014. A Comparative Study on Efficiency of Two Different Circulation Modes of Agricultural Products Based on DEA Model: Wholesale Market and Logistics Distribution Centre. Computer Modelling and New Technologies 18(7):175-180.

Firdaussy Y. 2012. Analisa integrasi pasar dan transmisi harga beras petani-konsumen di Indonesia [tesis]. Jakarta: Fakultas Ekonomi, Universitas Indonesia.

Hermawan A, Sarjana, Pertiwi MD, Ambarsari I. 2008. Informasi asimetris dalam transmisi harga gabah dan harga beras. Jurnal Litbang Provinsi Jawa Tengah 6(1):61-72.

Jezghani F, Moghaddasi R, Yazdani S, Mohamadinejad A. 2011. Price transmission mechanism in the iranian rice market. International Journal of Agricultural Science and Research 2(4):31-38.

Juanda B, Junaidi. 2012. Ekonometrika Deret Waktu. Bogor: IPB Press.

Lokollo EM. 2012. Bunga Rampai Rantai Pasok Komoditas Pertanian Indonesia. Bogor: IPB Press. 
Mardianto S, Supriatna Y, Agustin NK. 2005. Dinamika pola pemasaran gabah dan beras di Indonesia. Forum Penelitian Agro Ekonomi 23(2):116-131. https://doi.org/10.21082/fae.v23n2.2005.116131.

Mafimisebi TE, Agunbiade BO, Mafimisebi OE. 2014. Price variability, co-integration and exogeniety in the market for locally produced rice: a case study of Southwest Zone of Nigeria. Rice Research: Open Access 2(1):1-6.

Meyer J, Taubadel SVC. 2004. Asymetric price transmission: a survey. Journal of Agricultural Economics 55(3): 581-611. https://doi. org/10.1111/j.1477-9552.2004.tb00116.x.

Mkpado M, Arene CJ, Ifejirika CA. 2013. Price transmission and integration of rural and urban rice markets in Nigeria. Journal of Agriculture and Sustainability 2(1): 66-85.

Ohen SB, Abang SO. 2011. Evaluation of price linkages within the supply chain of rice markets in Cross River State, Nigeria. Journal of Agriculture and Social Research 11(1):156-163.

Purwono J, Sugyaningsih S, Priambudi A. 2013. Analisis tataniaga beras di Kecamatan Rogojampi Kabupaten Banyuwangi. Jurnal NeO-Bis
7(2):136-150.

[PUSDATIN] Pusat Data dan Sistem Informasi Pertanian. 2016. Buletin Konsumsi Pangan. http://pusdatin.setjen.pertanian.go.id/ [17 Maret 2017].

Saragih AE. 2015. Sistem pemasaran beras ciherang di Kecamatan Cibeber, Kabupaten Cianjur. Jurnal Ilmiah Forum Agribisnis 5(1):1-24.

Sobichin M. 2012. Nilai rantai distribusi komoditas gabah dan beras di Kabupaten Batang. Economics Development Analysis Journal 1(2):2-9.

Sultana A. 2012. Rice marketing in bangladesh: from the perspective of village study at cox's bazar district. African Journal of Agricultural Research 7(45):5995-6004.https://doi.org/10.5897/ AJAR12.1840.

Surjasa D, Sa'id EG, Arifin B, Sukardi, Jie F. 2013. Indonesian rice supply chain analysis and supplier selection model. International Journal of Information, Business and Management 5(1):198-212.

Van der Vorst. 2006. Peformance Measurement in AgriFood Supply Chain Networks. Wageningen: Wageningen Academic Publishers. 